\title{
The Member States, the National Constitutions and the Scope of the Charter
}

The Charter for Fundamental Rights is, if not its own child, a god child of Germany. Due to the efforts of the German government alone, the consolidation of the protection of fundamental rights within the European Union came on the agenda of the European Council. During the German presidency it was decided to convene a body of representatives of the heads of state and governments and of the parliaments to draw up a charter of fundamental rights - a procedure further elaborated at the Tampere meeting of the European Council. By putting forward as representative of the German government a former head of state, who was not only an outstanding expert in constitutional law, but had also been a member and president of the constitutional court that had forced the Court of Justice of the European Communities into recognizing the relevance of fundamental rights to EC law, it became virtually impossible not to have him elected as president of the body charged with drawing up the Charter. Thus, also decisive influence on the actual process of drawing up the Charter was in German hands.

The impetus for this German initiative was not merely political but constitutional. Article 23 of the Grundgesetz imposes the duty "participate in the development of the European Union which [...] provides a protection of fundamental rights essentially equivalent to that of this Constitution."1 The perception was that this required more than the open formulation of Article 6 (2) of the TEU, and the protection provided by the Court of Justice needed a clearer articulation of the actual rights so protected. Also, the assumption underlying this national constitutional provision is that EU and EC measures, or national measures required by EU and EC, enter into the field of competence to which the national constitution applies - otherwise there would not need to be a national constitutional concern about protecting fundamental rights as protected by the national constitution itself.

Two questions can therefore be raised as concerns the Charter as eventually adopted: what is the relation between the Charter and national constitutions; and what is the scope of the Charter as concerns Member States' action. I address these questions briefly in this essay. Finally, we briefly turn to the question whether the Charter has in effect provided what the German Constitution asked for.

\section{European status of national constitutions}

European Community law has had a most ambivalent attitude towards national constitutions. If a provision of national law stands in the way of the direct effect of Community law, it has to be disregarded by all authorities concerned, whether executive or judicial, of central, decentralized, federal or state, regardless of whether it concerns a constitutional provision dealing with fundamental human rights, constitutional provisions of an institutional nature, provisions of acts of parliament or of any other status (ECJ case 106/77, Simmenthal esp. p. 645).

\footnotetext{
${ }^{1}$ Article 23(1): "To realize a unified Europe, Germany participates in the development of the European Union which is bound to democratic, rule of law, social, and federal principles as well as the principle of subsidiarity and provides a protection of fundamental rights essentially equivalent to that of this Constitution."
} 
On the other hand the national constitutions in so far as they constitute a "constitutional tradition common to the Member States" are a source of inspiration on which the Court of Justice draws when providing fundamental rights protection. Clearly, this was by way of mitigation of the consequences to which a strict application of the Simmenthal principle might lead. As intimated and is well known, it required the threat of a revolt by national courts before the Court took this stance. The Charter can be researched for traces of the national constituional traditions

Traces of the national constitutional traditions in the Charter

First of all, the Preamble mentions the national constitutional traditions:

"This Charter reaffirms, [...], the rights as they result, in particular, from the constitutional traditions and international obligations common to the Member States, the Treaty on European Union, the Community Treaties, the European Convention for the Protection of Human Rights and Fundamental Freedoms, the Social Charters adopted by the Community and by the Council of Europe and the case law of the Court of Justice of the European Communities and of the European Court of Human Rights."

This is a remarkable new formulation which diverges in significant respects from Article 6 (2) TEU. Here I limit myself to note that the place of the constitutional traditions is reversed: they come before the international engagements and sources. However, they also are nearly snowed in under the barrage of other sources of rights.

Before we take a cursory look at the contribution of national constitutions to the Charter, we must at the outset notice that the input is different for the various Member States. This is caused amongst other things by the different status which constitutional rights have in different states. For instance, the dualist states like Germany and Italy with strong constitutional courts and constitutional cultures have more at stake than for instance the Netherlands, with a weak constitutional culture and a relatively low degree of protection which citizens can derive from their constitutional rights. This also explains why the Dutch contribution $^{2}$ to the Charter centred heavily on the relationship to the ECHR. In fact, the Lower House of the Netherlands Parliament threatened to pass a resolution instructing the Prime Minister not to agree with the Charter at the Nice summit, as it had come under the impression that the Charter might lead to divergences from the ECHR and from Strasbourg case law. That this was much more acutely the case under Community law previous to the Charter than under the Charter, passed unnoticed.

In its final version, the Charter refers to the constitutional traditions common to the Member States firstly with regard to the right to conscientious objection in accordance with the national laws (Article 10 (2)), in the explanatory memorandum of the Presidium of the Convention attached to the Charter. Interestingly, the explanation - like the formulation of this provision - refers in one breath to national constitutional traditions "and to the development of national legislation on this issue". When we look to the Greek Constitution, this is a controversial statement, which makes its importance as a fundamental right more

\footnotetext{
${ }^{2}$ It is difficult to assess this in detail, because the proceedings of the actual meetings of the "Convention" have - with one exception - not been published. The Dutch were the largest single nationality represented in the "Convention", with in total ten members (including the "membres suppléants").
} 
relative than it might seem at first sight. ${ }^{3}$

Article 17 (1) opens with: "Everyone has the right to own, use, dispose of and bequeath his or her lawfully acquired possessions." In the explanatory document, this is said to be "a fundamental right common to all national constitutions." One will look for it in vain in the present Constitution of the Kingdom of the Netherlands: it only contains a provision on compensation if in the public interest a competent authority destroys property, renders it unusable or restricts the exercise of the owner's rights to it. The Constitution does not know a right to own, use, dispose of or bequeath possessions. The situation in the UK seems to be not very different. The same must be said on Article 20, equality before the law, which according to the explanation is to be found in all European constitutions: it was removed from the Netherlands Constitution in 1983, instead of which we only have a prohibition of discrimination (in practice of narrower impact than the non-discrimination clause of Article 21 Charter). The principle of proportionality between punishment and crime (Article 49 (3)), is also said to be "enshrined in the common constitutional traditions of the Member States"; this may be a principle everywhere, but that is not to say that this principle has constitutional status everywhere.

These examples illustrate the uncertainty as to the scope of the category of "constitutional traditions". In the few cases in which the Charter's explanatory memorandum refers to these traditions, it does not succeed in establishing that in fact they are common to the Member States. Whereas the Court of Justice had made clear that if the nature and extent of the protection differ too much among the legal systems of the Member States, there cannot be a common constitutional tradition with regard to a particular right, ${ }^{4}$ the Charter seems to include rights which do not have equal protection in all Member States. Nor is it clear where a constitutional tradition begins and ends. It seems that the Charter sometimes relies on principles which do not have constitutional status in all Member States.

A further case in point is Article 14, the right to education and to found educational establishments with "due respect for democratic principles", which is said to be based on "the common constitutional traditions of Member States" and the ECHR First Protocol. Here "common" means: the lowest common denominator. Precisely with respect to the right to and freedom of education there are great differences in the various Member States' constiutional tradition, which ranges from a constitutional prohibition of state funding of private education (Italy) ${ }^{5}$ to a constitutional guarantee that private education is state funded on the same footing as publicly organized education (Netherlands). ${ }^{6}$ The "due respect"

${ }^{3}$ Constitution, Article 13 (2): "Proselytism is prohibited. ... (4) No person shall be exempt from discharging his obligations to the State or may refuse to comply with the laws by reason of his religious convictions."

${ }^{4}$ ECJ, joint cases 46/87 and 227/88, Hoechst, para 17.

${ }^{5}$ Constitution of the Italian Republic, Article 33 (3): "Enti privati hanno il diritto di istituire scuole ed istituti di educazione, senza oneri per lo Stato." Massimo Luciani, in Stato della Costitutizione, Guido Neppi Modona (ed.), Milano 1995, p. 134: "Da tale disposizione consegue che lo Stato non possa in alcun modo erogare finanziamenti o altre forme di sostegno economico in favore della scuola privata."

${ }^{6}$ Netherlands Constitution Article 23 (6 and 7): "The requirements for primary education shall be such that the standards both of private schools fully financed from public funds and of public-authority schools are fully guaranteed. The relevant provisions shall respect in particular the freedom of private 
clause is a neat cover for these differences: in Italy democratic principles (understood in a republican sense) are considered to entail the constitutional prohibition of public financial support, in the Netherlands they (on the basis of democratic societal differentiation) are considered to entail the constitutional guarantee of public financial support.

The explanation of Article 37, which imposes the duty to include environmental considerations into policies and politics, says that it "also draws on the provisions of some national constitutions." It is the only explicit reference to a "fundamental right" which is enshrined only in some constitutions. ${ }^{7}$

Relation between national constitutional provisions and EU human rights standard The above raises the question of the relationship between the various constitutions and the level of protection they provide. This is the topic of Article 53 of the Charter:

"Nothing in this Charter shall be interpreted as restricting or adversely affecting
human rights and fundamental freedoms as recognised, in their respective fields of
application, by Union law and international law and by international agreements to
which the Union, the Community or all the Member States are party, including the
European Convention for the Protection of Human Rights and Fundamental
Freedoms, and by the Member States' constitutions."

In the abstract three situations can be distinguished in the relationship between the EU and a Member State bill of rights:

a) the Member State bill of rights contains the same rights as the EU bill of rights; this may be the case when the EU constitution simply repeats the national rights, or when it refers to them as part of the EU constitution;

b) the Member State bill of rights provides less protection to citizens than the EU bill of rights does; at the level of norms, this may be the consequence either of the nonexistence of an equivalent of an EU right on the national level, a narrower scope of the right, or due to the state right allowing more restrictions than the federal rights do;

c) the Member State bill of rights provides more protection to citizens than the EU bill of rights does; again, this may be either because a right is formulated more broadly than a similar EU right (or a Member State constitution may recognize a right as fundamental which is not a fundamental right under the EU Charter) or it

schools to choose their teaching aids and to appoint teachers as they see fit. 7. Private primary schools that satisfy the conditions laid down by act of parliament shall be financed from public funds according to the same standards as public-authority schools. The conditions under which private secondary education and pre-university education shall receive contributions from public funds shall be laid down by act of parliament."

${ }^{7} \mathrm{Cf}$. the explanation of Article 49 (1), third sentence, containing the principle of the retroactivity of a more lenient penal law, which is said to exist "in a number of Member States", can be taken as another such reference. In the Netherlands codifies in Article 1 (2) of the Penal Code, Wetboek van Strafrecht this firmly established principle, but the Constitution of 1983 failed to include it as an exception to the prohibition of retroactive effect of provisions of criminal law; see L.F.M. Besselink, De intertemporele werking van rechtsregels en rechtszekerheid, Tijdschrift voor Bestuurswetenschappen en Publiekrecht, 1991 (46) nr. 3, pp. 174-179. 
allows authorities fewer possibilities for restricting the exercise of a right than the EU provisions do with regard to a similar EU right.

Given the wording of Article 53 ("restricting or adversely affecting"), it has in view situation (c). Article 53 suggests that the Charter shall not adversely affect the rights contained in national constitutions, EU law, and international treaty law "recognized in their respective fields of application". These last words are somewhat puzzling. I return to this presently.

The primary and clear meaning of Article 53 is that the Charter establishes a minimum standard which does not do away with higher existent standards. If in EU law, for instance under the EC treaty, certain rights are protected in a manner not specified in the Charter, the Charter cannot be interpreted to diminish that existent EC right. Thus one can think of the economic rights of free movement of goods and capital, which the Court of Justice has called "fundamental freedoms". These are perhaps encapsulated in the freedom to choose an occupation, the right to work and to conduct a business (Articles 15 and 16), but not as explicitly and well defined as in Community law. Also, Article 53 gives an unambiguous guarantee that the Charter is not able to affect the level of protection granted under the European Convention of Human Rights.

More problematic is Article 53 with regard to other international human rights treaties and to the national constitutions.

As to the international human rights treaties the minimum guarantee is restricted to those to which "the Union, the Community or all the Member States" are a party. As far as the Union is concerned, the Charter is future oriented, because at the moment it has no international legal capacity to engage into treaties indepedently from the Member States; and (pace academics who think differently) even if it could do so, it has not. Also the Community has, as far as I can see, not yet become a party to a human rights treaty. The real difficulty is in the formulation that the non-derogatory effect is only stipulated with regard to treaties to which all Member States are a party - a formulation which was introduced at a fairly late stage. Earlier versions omitted the word "all". The present formulation may imply that the Charter can be interpreted to derogate from, restrict and adversely affect the rights and freedoms stipulated in human rights treaties to which only some Member States (or only one) are a party. If the Charter is to have any legal meaning and I assume that this is the case even if it is not elevated to a treaty text, but merely taken as an authoritative articulation of the fundamental rights which are protected as a general principle of Community or Union law - this creates a potential conflict of international obligations. I will not here discuss the consequences in terms of public international law, but limit myself to remark that under Netherlands constitutional law, courts consider themselves under the constitutional obligation autonomously to solve this conflict. In practice, Dutch courts will have to balance the interest of the individual in having his rights under the relevant human rights treaty respected against the interest in enforcing Union or Community law, just as they have in the past balanced the interest of a person in being protected in his rights under the ECHR against the interest of applying conflicting rules of the NATO Status Agreement. ${ }^{8}$ It may well be that this balancing is to the advantage of

\footnotetext{
${ }^{8}$ The Hoge Raad [Supreme Court] of the Netherlands decided in the Cruise Missile case that "[t]here is no rule, either [...] in the Constitution or any other rule of the (national) law of the Netherlands, which stands in the way for a Netherlands court to review whether a treaty [...] is in conflict with other treaties or other norms of public international law"; HR 10 November 1989, NJ 1990, 450, para. 3.4. In HR
} 
protecting fundamental rights. The problem may become urgent with respect to the Protocols to the ECHR. In the explanation to Article 52, it is suggested that the equivalence of protection refers both to the ECHR itself as well as to the Protocols. But the text of Article 53 implies that this regards only the Protocols to which all Member States are a party. It this were otherwise, unexplained (and as far as I can see: unjustified) distinctions arise between the ECHR protocols and other human rights treaties, such as the newly revised European Social Charter.

As to the national constitutions, the problem also resides in the plural: it concerns rights "as recognized by the Member States' constitutions". This is a formulation which might be interpreted, in line with the treaties to which all Member States should be a party, as referring to the rights and freedoms which are recognized by all Member State constitutions. In fact, the history of this provision does not provide a clear argument for this farreaching interpretation. In earlier versions, ${ }^{9}$ mention is made of "the law of the Member States". This does not at all imply that it concerns any uniformly existent law of all the Member States. In a document of 16 May 2000 the wording was changed from "the law" to "the constitutions" of the Member States. ${ }^{10}$ Against this background the view that the Charter should only respect the rights and freedoms as recognized by the constitutions of all Member States, is not warranted. Another argument against this farreaching interpretation is that it is unlikely that the framers of the Charter would take a very loose concept of "the constitutional traditions common to the Member States" as sufficient for including certain rights as worthy of protection at the EU level. It would be inconsistent to be very strict in not respecting constitutional rights except those protected in all Member States.

\section{The "respective fields of application"}

I turn to the issue of the meaning of the words "as recognized in their respective fields of application" in Article 53. What are they intended to add? It would seem self-evident that the rights of Member States' constitutions are recognized in their own field of application; and this must also be the case with the EU and other international treaty rights.

The addition of the words "in their respective fields of application" suggests separate fields of application with which the Charter does not wish to interfere. Somehow one senses the intention to force those various fundamental rights back into their own fields of application: we won't interfere with you, as long as you will not interfere with us. It sounds like a call for an armistice between the EU/EC and the national constitutional practices which have claimed that constitutional rights can be an obstacle to the direct effect of Community law; an armistice based on the drawing of boundaries between the "respective

30 March 1990, NJ 1991, 249 (Short), it involved on the one hand the treaty obligation under the NATO Status Agreement (Article VII, para. 3) to deliver an American soldier within the Netherlands' jurisdiction, who had confessed he had murdered his wife, to the American military authorities; and on the other the treaty obligation under the European Convention on Human Rights, which forbids the imposition of the death penalty (Art. 1, Sixth Protocol in conjunction with ECHR 7 July 1989 Soering, Series A nr. 161); the case was decided in favour of protecting the ECHR rights.

${ }^{9}$ Convent 27, 18 April 2000, Charte 4235/00, Article H 4.

${ }^{10}$ Charte 4316/00, d.d. 16 mei 2000, Convent 34, Article 49. 
fields of application". The question is whether this tactics - if at all intended - could work. Theoretically, the various (national, EU and international) rights and freedoms may each apply within their own fields. But are these "fields" in the present state of EU law (and international law for that matter) practically separate? Is there no overlap? Are they perhaps co-extensive? And what about national constitutional law: does it think itself as quite separate and having nothing to do with any of the "fields of application" of EU law?

The argument for saying that they are not co-extensive, that there is an overlap and that the fields of application are not separate, is Article 53 of the Charter itself. For what could be the sense of Article 53, if not that the Charter might at least potentially conflict with other national constitutional and international treaty rights and freedoms?

For the moment it is clear that the "field" of national constitutions according to national constitutional law is not entirely separate from that of EU/EC law. The Maastricht and Fragd judgments of the German and Italian constitutional courts make clear that the protection of their constitutional rights is indeed relevant in matters of Community law. So do all the changes which other Member States felt constrained to make upon accession or adoption of the Maastricht and Amsterdam treaties, including Article 23 of the Grundgesetz quoted above. Constitutional law in most Member States does not find itself irrelevant to EU and EC law, and, one must assume, nor to the fields which the Charter wishes to cover. This leads us to the question: what is the "field" in which the Charter is deemed applicable?

The "field of application" of the Charter

This question is supposedly answered by Article 51 (1):

"Scope

1. The provisions of this Charter are addressed to the institutions and bodies of the Union with due regard for the principle of subsidiarity and to the Member States only when they are implementing Union law. They shall therefore respect the rights, observe the principles and promote the application thereof in accordance with their respective powers." (Italics added)

Here we concentrate on the application of the Charter to Member State action. The explanation reads on this point:

"As regards the Member States, it follows unambiguously from the case law of the Court of Justice that the requirement to respect fundamental rights defined in a Union context is only binding on the Member States when they act in the context of Community law (judgment of 13 July 1989, Case 5/88 Wachauf [1989] ECR 2609; judgment of 18 June 1991, ERT [1991] ECR I-2925). The Court of Justice recently confirmed this case law in the following terms: "In addition, it should be remembered that the requirements flowing from the protection of fundamental rights in the Community legal order are also binding on Member States when they implement Community rules..." (judgment of 13 April 2000, Case C-292/97, paragraph 37 of the grounds, not yet published). Of course this principle, as enshrined in this Charter, applies to the central authorities as well as to regional or local bodies, and to public organisations, when they are implementing Union law."

This makes for a very interesting concoction of formulations. The term "implementation of EU/EC law" which the Charter provision uses is in normal European law parlance by no means the same as "acting in the context of EU/EC law". Actually, the case law of the ECJ does not use the latter expression, but the expression "within the scope of Community law". 
The explanation seems to neutralize the text of the provision, but given the legal status of the explanation, it is probably unable to do so.

Member State action ranges from that which is generated by EC law and is evidently within the core of EC law to autonomous state action of which the relation with EC law needs each time to be established. At least three kinds of Member State action can be distinguished: implementation;

Member State action under an explicit exception to an EC right (especially the economic freedoms);

and Member State action under the unwritten rule of reason (Cassis de Dijon) exceptions which place a certain action outside the scope of the prohibitions on infringing the economic freedoms (mandatory requirements to serve legitimate objectives in a manner which is not disproportionate and does not discriminate in the EC sense). ${ }^{11}$

When implementing in the strict sense, that is to say, when giving a Community law measure the necessary "hands and feet" for it to become effective, Member State action is clearly governed by Community law, and therefore subject to the scrutiny of the European institutions, including the ECJ. In this case the Member State is governed by EC law of an attributive function towards the Member States: Member States have to perform functions attributed to them by EC law with regard to a certain subject matter. The Member State in this capacity can be described in various ways: when implementing, it is acting as integral part, as the "agent" or the long arm of the EC/ EU. Typical examples are the implementation of directives and other acts in the sphere of "positive" integration.

Often Member States can act autonomously, in the sense that they engage in an act which does not have the EC as its efficient cause and is yet governed by EC law. In this case, EC law is not constitutive or attributive, but merely regulative with regard to Member State action. Main examples are the economic freedoms and other rules in the sphere of "negative" integration. The Member State action here intended, is scrutinized by the ECJ when it is situated within the remit of relevant norms of EC law (which I refer to as "situation a"); but also the question whether certain Member State action is within the remit of EC law ("situation b") is scrutinized by the ECJ. Because there sometimes is confusion about this important issue, I wish to restate the crucial difference between these two situations.

It is clear that when the Court adjudicates whether a restriction of free movement under Articles 30 (formerly 36), 39 paragraph 3 (formerly 48 (3)) or 46 (formerly 56) EC is lawful, it is adjudicating a matter which is by definition within the remit of EC law, to wit the matter is within the remit of Articles 28 and 29, 39 (1), 43, or 49 and $50 \mathrm{EC}$. This is a "situation a" case, because logically, it must first have been established that we are dealing with quantative restrictions, free movement of workers, freedom of establishment or to provide services in the sense of Community law, before we can assess whether a restriction thereof was justified. This latter assessment is entirely within the framework of Community law even if one is dealing with criteria such as the public policy and public security of Member States. It is unsurprising that the Court has judged that the limitations of the EC freedoms imposed by Member State measures must be appraised in the light of the general principles of Community law, including the fundamental rights (case C-260/89, $E R T)$.

\footnotetext{
${ }^{11}$ Certain forms of potentially justified unequal treatment hinge on considerations similar to those in the last mentioned category.
} 
Quite different is the situation in which the Court assesses whether certain Member State action is at all within the remit of one of the provisions of Community law, that is to say, whether it is at all within the sphere of the free movement of goods, persons, services, etc.. The 'rule of reason' exceptions are a case in point. When the Court judges certain Member State action to be justified under the rule of reason criteria, that action is no longer within the remit of the relevant freedom. One would think this implies that as soon as it involves such justified Member States action, the relevant measures are no longer within the scope of Community law. No further EC/ EU fundamental rights can apply. This is classically formulated in Cinéthèque and Demirel. ${ }^{12}$ However, the Court has arguably overturned this case law in Familiapress. ${ }^{13}$ This case concerned the question whether the prohibition of periodicals which contain games with which money prizes can be won, was in conflict with the former Article 30 (now 28) EC. The Court considered whether this measure comes within the scope of Article 30 (now 28) EC - so we are dealing with a "situation b" case. Article 10 ECHR played two different roles. Firstly, upholding the pluriformity of the press under $10 \mathrm{ECHR}$ may in the view of the Court be a justification which brings this Member State measure outside the scope of Article 30 (28) EC. Secondly, the Member State measure involved can, according to the Court, interfere with the freedom of expression under Article $10 \mathrm{ECHR}$, although it may be justified under the second paragraph of this provision. In this latter context, the Court holds that the mandatory requirements which may bring a Member State measure outside the scope of Community law, must be interpreted as requiring conformity with general principles of Community law, especially the fundamental rights which are part thereof. The Court here referred to ERT (para. 24) obviously failing to distinguish that in ERT the situation was not one of determining whether a Member State measure came at all within the scope of free movement of services - which was established - but with the question whether a restriction of that free movement was justified, whereas in Familiapress the question was whether the Member State measure came at all within the scope of the free movement of goods. In other words the Court in Familiapress failed to distinguish any longer (as it had done in, for instance, Cinéthèque) that ERT dealt with a "situation a" case, whereas Familiapress concerned a "situation b" case. Curiously the Court in its dispositive did not make specific mention of this particular aspect of the freedom of expression under Article $10 \mathrm{ECHR}$ to which the Member State elsewhere in the judgment is held to comply. Also, it is hard exactly to reconstruct the logic of why Member States are held to do so if the measure would for all other reasons turn out to be outside the scope of Community law (in this particular case: the necessity to maintain press pluriformity as required by Article 10 ECHR itself). Nevertheless, Familiapress seems to imply that all Member State action in order to stand the test of the "rule of reason", must comply with the EC/ EU fundamental rights standard. ${ }^{14}$ This means a further expansion of

\footnotetext{
${ }^{12}$ ECJ cases 60 and 61/84, and C-12/86.

${ }^{13}$ Case 368/95, Familiapress.

${ }^{14}$ Somewhat differently Duijkersloot, in: Grenzen aan grenzenloosheid, L.F.M. Besselink and
} H.R.B.M. Kummeling (eds.), Deventer 1998, who takes the fundamental rights requirement to be essentially a proportionality requirement, but not to require aseparate conformity with fundamental rights. Otherwise, A.W. Hins en J.L. de Reede, Grondrechten, Europese integratie en nationale soevereiniteit, in: Europese Unie en nationale soevereiniteit, Deventer 1997, p. 8-10. 
the EU standard outside previous confines. However, this is not entirely limitless. It would seem that the EU standard applies as soon as there is a prima facie case that the relevant Member State measure comes within the scope of relevant Community law and only a further rule of reason test would lead to the conclusion that that measure is outside the scope of Community law. Only measures which neither implement Community law nor otherwise touch in any manner upon Community law, are outside the reach of the EU fundamental rights standard. ${ }^{15}$ So there still is no absolute supremacy of the EU fundamental rights standard over just any Member State action from the ECJ's point of view.

It is evident that the wording of Article 51 (1) of the Charter is much more restrictive than the case law we describe. Clearly, when Member States implement EC law, the EU standard applies. ${ }^{16}$ Unless this wording means more than it says - and the explanatory memorandum gives rise to this suspicion - this may be understood as a signalling the Court to reverse its case law. ${ }^{17}$ Clearly, the justification of a restriction of a free movement right must take into account the principles of Community law, and therefore also the EC fundamental rights, just as any other Member State act which is squarely covered by EC law regulative norms. The reference in the explanatory memorandum to $E R T$ may be taken to reflect this view. Potentially, this reference may even lead to the broader view which the Court adopted when extending ERT even to the rule of reason cases (Familiapress) - thus it arguably intrudes into the Member State measures which otherwise are outside the scope of Community law. But it can hardly be doubted whether it is in the power of explanatory memoranda to bend the clear meaning of words in the actual text of the Charter: it is not. Future practice, however, may show which view will prevail.

\section{Conclusion}

The Charter has given an inclusive account of the fundamental rights to be protected in EU law. In doing so it has included certain rights which can be found in varioius national constitutions. In the process it has diverged crucially from the strict definition of constitutional traditions "common to the Member States" which the Court of Justice gave in the Hoechst judgments.

To the extent that the rights of the Charter may prove insufficient in protecting existent constitutional rights, Article 53 of the Charter stipulates that it does not do away with rights provided by the "constitutions" of Member States and human rights treaties to which all of them are a party. In dualist countries like Germany, particularly the constitutional rights are important. If Article 53 is to be understood as only respecting rights recognized in most member state constitutions, the Germans may not have received in the

${ }^{15}$ See e.g. case 291/96, Grado and Bashir, 9 October 1997 case 309/96, Annibali, 18 December 1997, both chamber judgements from after Familiapress, which was decided by the plenary court.

${ }^{16}$ This is confirmed in Annibaldi, para. 21.

${ }^{17}$ Thus Lenaerts already pointed out that the new formulations of the Amsterdam Treaty as referring to the institutions, was signal for caution by the Court, Respect for Fundamental Rights as a Constitutional Principle of the European Union, the Columbia Journal of European Law, vol. 6, no.1 2000, p. 21. 
Charter what their Constitutional asks for; however, if Article 53 protects the primacy of any constitutional right, the equivalent protection which the German Constitution requires from EU law is guaranteed. This, in turn, would mean an official recognition of the exception to Community law supremacy, which national constitutional courts, like the Italian and German have insisted on.

In monist countries like the Netherlands, where international treaties enjoy supremacy, national courts may be confronted with international human rights treaties to which not all Member States are a party. In this case they will have to balance the rights awarded by these treaties to parties involved in litigation against the duty to conform with Community (or EU) obligations, which may not necessarily be to the advantage of EC or EU law.

As to the scope of the Charter: this is formulated in a manner which suggests a more restricted conception of the scope of Community law then is suggested in the ECJ case law (Article 51 Charter). This may on the face of it leave more room for Member State institutions for complying with their own constitutional requirements.

All this means that some 'local' variation in the conception and implications of fundamental rights protection may arise. Such variation may interfere with the supremacy of EC law, but also with the 'fundamental' nature of fundamental rights. On the other hand it is a recognition of the plurality and non-homogeneity of values in Europe, which intertwine in this confluence of legal orders which is the European Union. 